\title{
Repititive, iterative and habitual aspectual affixes in West Greenlandic
}

\author{
Trondhjem, Naja Blytmann
}

Published in:

Acta Hafniensia Linguistica, International journal of linguistics

DOI:

10.1080/03740463.2011.735475

Publication date:

2012

Document version

Publisher's PDF, also known as Version of record

Citation for published version (APA):

Trondhjem, N. B. (2012). Repititive, iterative and habitual aspectual affixes in West Greenlandic. Acta Hafniensia Linguistica, International journal of linguistics, 44(1 (2012)), 64-76.

https://doi.org/10.1080/03740463.2011.735475 
This article was downloaded by: [Copenhagen University Library]

On: 27 March 2014, At: 03:41

Publisher: Routledge

Informa Ltd Registered in England and Wales Registered Number: 1072954

Registered office: Mortimer House, 37-41 Mortimer Street, London W1T 3J H, UK

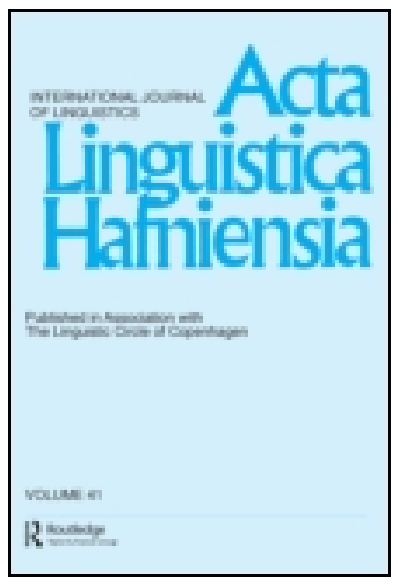

\section{Acta Linguistica Hafniensia: International J ournal of Linguistics}

Publication details, including instructions for authors and subscription information:

http:/ / www. tandfonline.com/ loi/ salh20

\section{Repetitive, iterative and habitual aspectual affixes in West Greenlandic}

Naja Blytmann Trondhjem ${ }^{a}$

a Department of Cross-Cultural and Regional

Studies, Eskimology and Arctic Section, University of Copenhagen, Denmark

Published online: 22 Oct 2013.

To cite this article: Naja Blytmann Trondhjem (2012) Repetitive, iterative and habitual aspectual affixes in West Greenlandic, Acta Linguistica Hafniensia: International J ournal of Linguistics, 44:1, 64-76, DOI: 10.1080/ 03740463.2011.735475

To link to this article: http:/ / dx. doi.org/ 10.1080/ 03740463.2011.735475

\section{PLEASE SCROLL DOWN FOR ARTICLE}

Taylor \& Francis makes every effort to ensure the accuracy of all the information (the "Content") contained in the publications on our platform. However, Taylor \& Francis, our agents, and our licensors make no representations or warranties whatsoever as to the accuracy, completeness, or suitability for any purpose of the Content. Any opinions and views expressed in this publication are the opinions and views of the authors, and are not the views of or endorsed by Taylor \& Francis. The accuracy of the Content should not be relied upon and should be independently verified with primary sources of information. Taylor and Francis shall not be liable for any losses, actions, claims, proceedings, demands, costs, expenses, damages, and other liabilities whatsoever or howsoever caused arising directly or indirectly in connection with, in relation to or arising out of the use of the Content. 
This article may be used for research, teaching, and private study purposes. Any substantial or systematic reproduction, redistribution, reselling, loan, sublicensing, systematic supply, or distribution in any form to anyone is expressly forbidden. Terms \& Conditions of access and use can be found at http:// www.tandfonline.com/page/terms-and-conditions 


\title{
Repetitive, iterative and habitual aspectual affixes in West Greenlandic
}

\author{
Naja Blytmann Trondhjem*
Department of Cross-Cultural and Regional Studies, Eskimology and Arctic Section, University of Copenhagen, Denmark

\begin{abstract}
In West Greenlandic, there are about 50 to 60 derivational aspectual affixes, and some of them have more than one meaning: a concrete meaning and a temporal meaning. The aspectual affixes are divided into quantitative aspect and phasal aspect. The phasal aspectual affixes are further divided into "inner" phasal aspectual affixes with a verb-modifying function and scope over the verb stem, and "outer" phasal aspectual affixes with a sentencemodifying function and scope over the sentence. Most of the tense affixes are polysemous and also belong to both inner and outer phasal aspects such as -ler 'begin, be about to, near future'. Among the quantitative aspectual affixes, a group of aspectual affixes contain an iterative/habitual/repetitive meaning. Of these, the most general affix is -tar/-sar, which seems to contain iterative, habitual, generic and gnomic meanings. According to Kristoffersen, -sar has a verb-modifying function with scope over the verbal stem, and a sentence-modifying function with scope over the sentence. There are a few other aspectual affixes with meanings that suggest iteration and repeated action, such as -llattaar 'from time to time', - qattaar 'repeatedly' etc., where the meanings are more concrete, purely aspectual and seem to be only verb-modifying compared to -tar/-sar 'habitually', which has a more general and tense-like meaning. In this paper, I examine the contexts in which the more concrete iterative/repetitive meanings are used in comparison to the more general repetitive and habitual meanings of -tar/-sar, and the combination of -tar/-sar with other affixes of iteration and repetition.
\end{abstract}

Keywords: West Greenlandic; habitual aspect; affixes; change

\section{Introduction}

Aspect in West Greenlandic is manifested by grammatical derivational affixes and by the inherent meaning of the verb stem (aktionsart). There are about 50-60 grammatical derivational aspectual affixes, which are divided into two groups: the quantitative aspectual affixes, including distributional, repetitive and habitual events; and phasal aspectual affixes, which are further divided into an inner phasal aspect and an outer phasal aspect, indicating different kinds of internal time for events. Some phasal aspectual affixes have developed polysemous meanings, where it seems that the same aspectual affix with scope over the verb

\footnotetext{
*Email: trondhjem@hum.ku.dk
} 
stem has also gained scope over the sentence; for example, -ler 'begin, about to, near future'. With the first meaning 'begin', -ler has scope over the verb stem and belongs to the inner phasal aspect category, and with the second and third meanings, -ler has scope over the sentence. With the meaning 'be about to', -ler belongs to the outer phasal aspect, and with the meaning 'near future', which seems to have developed during the last few decades, -ler belongs to the tense affixes. Thus, the order of the phasal aspectual affixes and the tense is as follows:

$$
\text { Stem }+ \text { inner phasal aspect }+ \text { outer phasal aspect }+ \text { tense }+ \text { inflection }
$$

The polysemic nature of the tense and aspectual affixes is a result of an ongoing grammaticalization process in which affixes with concrete meanings positioned near the stem receive more abstract meanings when the position shifts to the right near the inflection (Kristoffersen 1992; Fortescue 1996; Trondhjem 2007).

Most of the quantitative aspectual affixes have only one meaning, and do not exhibit this pattern. But some affixes - for example, -tar/-sar (-sar is added to vowel stems) 'repetitive (iterative), habitual' - seem to show a pattern of being both verb-modifying with a "repetitive" meaning and sentence-modifying with a 'habitual' meaning. The meanings of -tar include distinctions between distributive, iterative, habitual and generic/gnomic (Hagedorn, 1987, 101). Hagedorn (1987) and Kristoffersen (1992, 162ff.) assert that in some contexts -tar 'habitual' is obligatory like the tense affixes that it always precedes. Kristoffersen further states that -tar does not precede some verb-modifying affixes; for example, affixes of manner that have scope over the bare (core) predicate. In fact, there are examples of this kind of derivation, where all on one line is added to some specific semelfactive verb stems and then followed by manner affixes. These examples could demonstrate the same grammaticalization process as the tense affixes mentioned above; the repetitive habitual meanings were apparently already found in the 1850s (Kleinschmidt 1871). The quantitative affixes include semantic categories of "semelfactive/momentaneous; distributive/collective; repetitive; iterative/habitual (also serving as gnomic/generic); and continuative" (Kristoffersen 1992, 161). In this article, only repetitive, iterative and habitual affixes are described. It seems that -tar belongs to the iterative/habitual group, which is different from the group of repetitive affixes. The aim of this article is to demonstrate: (1) the semantic difference between the terms repetitive and iterative versus habitual seen in different contexts; and (2) the relative order in which the repetitive, iterative and habitual occur because more than one of these affixes can be combined with other aspectual or tense affixes.

\section{Iterative, repetitive and habitual aspects}

In general descriptions of quantitative aspects, it sometimes seems as though there is no distinction between the terms iterative and repetitive or frequentative (Cinque 1999, 91ff.), which makes it difficult to differentiate the meanings of the 
terms. Comrie (1976) defines the habitual aspect as "[...] a situation which is characteristic of an extended period of time, so extended in fact that the situation referred to is viewed not as an incidental property of the moment, but precisely as a characteristic feature of a whole period. If the individual situation is one that can be protracted indefinitely in time, then there is no need for iterativity to be involved" (Comrie 1976, 27ff.). Accordingly, an iterative situation cannot be protracted in time. The habitual is then a situation that is repeated over time as a habit or one that happens occasionally. The iterative aspect may be part of the habitual.

Bybee et al. (1994, 127) make a distinction between habitual, iterative and frequentative, where "habitual situations are customary, repeated on different occasions". Here, "frequentative includes habitual meaning - that a situation is characteristic of a period of time [...]" and that the situation is frequent in the specific period of time. Iteratives are also called repetitives, where events are repeated during a particular occasion. In this definition, the iterative is separated from the habitual meaning and points to one repeated event, while the frequentative includes habitual events.

In some languages, the same morpheme may cover the semantics of both iteratives/repetitives or frequentatives. In West Greenlandic, there are about 8 10 affixes that denote the habitual-frequentative aspect, and about 7 affixes that denote the iterative-repetitive aspect.

According to Hagedorn (1987) and Kristoffersen (1992), the habitualfrequentative group is called iterative-habitual aspectual affixes, and the iterative-repetitive group is called repetitive aspectual affixes. In this article, group terms from Hagedorn and Kristoffersen are used (e.g. iterative-habitual) to denote customary events.

\subsection{Iterative-habitual group}

The following iterative-habitual affixes are identified:

-sar/-tar (iterative-repetitive, habitual)

-kula (often)

- gajuC (often/inclined)

- nngisaannar (never)

-neq ajor - (negative habitual)

- qqatuC (rarely) ${ }^{1}$

$-j a$ (inclined/do easily)

-jaallu (early habitually)

$-(s) \operatorname{ari}$ (repeated/habitually)

-saannar (often/frequently)

\footnotetext{
${ }^{1}$ This affix seems to have different spellings/forms. As stated by Oqaatsit (Berthelsen et al. 1990) the spelling is -qqartor 'rarely', but the form -qqatuC 'rarely', seems to be more frequent today. The difference might be dialectal.
} 
The first five affixes seem to be used the most frequently, while the last five affixes are restricted to particular semantic areas and some of them may be more or less lexicalized. The focus is on -tar 'repeated/iterative, habitually' in comparison to the first four affixes in the first group. The rest of the affixes are only addressed briefly in the comparison.

The first one, -tar 'repeated, habitually', seems to have developed from a concrete meaning to more abstract meanings that can be iterative, habitual, generic and gnomic. According to Kristoffersen (1992), the abstract meaning of -tar has scope over the sentence and can be followed by sentential affixes, such as tense affixes; in the more concrete meaning, it has scope over the verb and, in this case, it can be followed by affixes that have scope over extended predications or propositions - like - qqu 'ask to' and - suri 'think that' - but not followed by affixes of manner, intensity or passive that have scope over the simple predication - like -juminar 'be easy to' - except when it is used with a distributive/collective aspect meaning (Kristoffersen 1992, 162).

However, it seems that -tar with the 'repetitive' meaning (single repeated action) is used in more or less lexicalized verb forms. This is in line with -sima 'state, perfect, past, epistemic modality', where the meaning of 'state' is used and more or less lexicalized - as in angerlarsimavoq 's/he is being at home' - but is productive when restricted to telic verb stems (Trondhjem 2007, 2009). This is an indication that it has also gained other meanings over time. In the 'repetitive' meaning, it can be followed by affixes of manner, intensity or passive; as discussed later, the distributive/collective aspect meaning seems to be implied by the inflection.

As described in older dictionaries, the meanings of -tar/-sar include 'repetitive, and habits or customs' (Egede 1760, 150, 158; Fabricius 1801, 311; Kleinschmidt 1871, 450 ff; Bergsland 1955, 120), where the repetitive meaning is dominant, and subsequent dictionaries include the habitual meaning in the more general sense. The repetitive meaning is still used, but it has a limited productivity in some specific transitive semelfactive verbs where the agent has + control, such as:

$$
\begin{aligned}
& i k u t-t a r-p a a \\
& \text { hack-REP-IND. 3SG.3SG } \\
& \text { 'S/he is hacking it' }
\end{aligned}
$$

These verbs are more or less lexicalized, and they denote the repeated action within the event. The situation is atelic, and here it describes the repeated movement of the arm. The stem of the verb ikuC- 'hack (once)' is a semelfactive verb, and it is still used in parallel to the semi-lexicalized form. Some other semelfactive verbs used with -tar are as follows: isattarpaa 's/he slaps him/her on the face repeatedly', where isaC- 'slap on the face (once)' is the stem; patittarpaa 's/he slaps him/her/it repeatedly', where patiC - 'slap (once)' is the stem; and naqittarpaa 's/he is pressing (something) down/kneading dough', 
where naqiC- 'press down (once)' is the stem. In this meaning, the verb can be followed by appropriate affixes of manner, intensity or passive:

$$
\begin{aligned}
& \text { ikut-tar-neqar-poq } \\
& \text { hack-REP'-PASS-IND.3SG } \\
& \text { 'It is being hacked repeatedly' }
\end{aligned}
$$

The repeated action of -tar, 'repetition' is different from other affixes of repetition, such as - qattaar 'repeatedly', -llattaar 'now and then/off and on' and a few others. These affixes, such as - qattaar and -llattaar, denote repetition of one situation in its entirety. Therefore, these affixes can be added to -tar 'repetition', as in:

$$
\begin{aligned}
& \text { ikut-ta-qattaar-paa } \\
& \text { hack-REP-REP-IND. 3SG.3SG } \\
& \text { 'S/he is hacking it repeatedly' }
\end{aligned}
$$

Here, the whole act of hacking (moving the arm) is repeated, and there are pauses in the hacking action. The combination -taqattaar 'repeatedly' is productive as a unit today, and it applies to all types of verbs - such as isertaqattaar - 'enters repeatedly' and igasaqattaar - 'cooks repeatedly', where the whole situation is repeated. But - qattaar 'repeated' is also productive with the same meaning as shown in iseqattaar - 'enters repeatedly' is possible. These two forms seem to be in some sort of competition.

The second repetition affix -llattaar 'now and then/off and on' is quite different from the first two because the repetition seems to happen often, but with a short duration.

$$
\begin{aligned}
& \text { ikut-ta-llattaar-paa } \\
& \text { hack-REP-REP.SHORTLY-IND. 3SG.3SG } \\
& \text { 'S/he is hacking it off and on' }
\end{aligned}
$$

Here, the situation of hacking is repeated intermittently, but the act of hacking itself has a short duration. The meaning becomes most clear when the affix is added to neri- 'eat' or nerillattaar - 'eats a bit on and off'. The meaning of iteration is used in specific contexts in connection with verbal quantification, where the stem is a numeral and the verbalising affix -riar 'do $x$ times' is present; for example, pingasoriar 'do three times':

$$
\begin{array}{ll}
\text { pingaso-riar-luni } & \text { seqqor-tar-poq } \\
\text { three-do.times-CONT }{ }^{3} .4 \mathrm{SG} & \text { crash-REP-IND.3SG } \\
\text { 'S/he crashed three times' } &
\end{array}
$$

\footnotetext{
${ }^{2}$ REP - repetitive.

${ }^{3}$ CONT - contemporative mood.
} 
The use of -tar 'repetition' seems to have once been more frequent since older people still use it that way, but this use is declining among young people, who seem to prefer seqqorpoq.

Kristoffersen $(1992,162)$ gives an example of the distributive and collective meaning of - tar as follows:

$$
\begin{aligned}
& \text { misilit-tar-neqar-luar-put } \\
& \text { test-HAB }{ }^{4} \text {-PASS - well-IND.3PL } \\
& \text { 'They (e.g. some methods) were thoroughly tried out/tested' }
\end{aligned}
$$

However, the meaning in this context is not 'distributive, collective' because the verb is acceptable in the third singular form - misilittarneqarluarpoq 'it was thoroughly tested' - and the meaning seems to be 'iteration/repetition' in line with (5) above. The meaning of -tar must be 'repetition', and it has nothing to do with the habitual meaning. These examples may be the starting point for meaning to be extended from pure repetition/iteration to suggesting a habit or customary act.

The meaning of a habit or customary act is productive with all kinds of verbs:

$$
\begin{aligned}
& \text { iser-tar-poq } \\
& \text { enter-ITE5-IND.3SG } \\
& \text { 'S/he visits regularly' (literally, 'X enters regularly') }
\end{aligned}
$$

In (7), it is indicated that someone visits regularly, but this action is not bound to any time. These kinds of habits can be more or less scheduled today (i.e. playing football every Sunday), and, when certain adverbs of time are added, then -tar is obligatory. According to Hagedorn (1987, 91ff.), there are three types of time specification: (1) specific time; (2) unspecific time; (3) conditional iteration/repetition.

The first and second types can be grouped together, where the adverb of time can be specific or unspecific. This happens quite often in the vialis case, as in:

$$
\begin{aligned}
& \text { unnuk-kut } \quad \text { suli-sar-poq } \\
& \text { evening-VIA }{ }^{6} \quad \text { work-HAB-IND.3SG } \\
& \text { 'S/he works in the evening' }
\end{aligned}
$$

Here, the person usually works in the evening. All kinds of punctual adverbs of time - usually in the vialis case - can be added to this kind of sentence, but other adverbs of time - such as ullut tamaasa 'every day' in absolutive case - are also used: the unspecific adverbs of time could be ilaanni 'sometimes', amerlanertigut 'more often than not' and qaqutigut 'rarely', the first in locative case and the last two in the vialis case.

\footnotetext{
${ }^{4} \mathrm{HAB}-$ habitual.

${ }^{5}$ ITE - iterative.

${ }^{6}$ VIA - vialis.
} 
The third type, a variation of causative mood, is used in complex sentences and indicate contingent or habitual time (Fortescue et al., 1994, 56): -gaanga 'every time, when', as in:

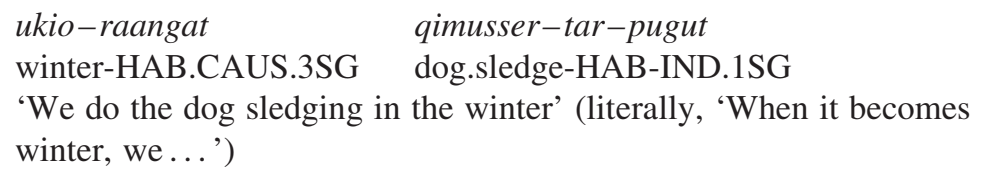

Here, the causative verb determines when the dog sledging happens.

A last group of obligatory markings is used to "bind" habits in some way; for example, to specific days, weeks or years. It is distinct from example (9) in that the custom somehow characterizes the performer. In this sense, the meaning of -tar can be compared to tense-like abstract meanings because it is obligatory and, in many contexts, it is not necessary to use an adverb of time. For example:

$$
\begin{aligned}
& \text { Arpat-tar-punga } \\
& \text { run-HAB-IND.1SG } \\
& \text { 'I (do) run' (a habit done twice a week) }
\end{aligned}
$$

Another habitual is used in parallel with this meaning, namely, $-(s)$ ari (repeated, habitual). This affix seems to be used more often in narratives and myths as well as modern stories, and it is fused with the indicative mood, as in - s/taraaq $(-s /$ tari + voq $)$.

$$
\begin{array}{ll}
\text { Iser-taraaq } & \text { nuannaar-luni } \\
\text { Enter-HAB.IND.3SG } & \text { be.glad-CONT.4SG } \\
\text { 'S/he always enters happily' }
\end{array}
$$

It is interesting to note that an imported modern habit like smoking allows both meanings, where the first meaning is repetition and the verb signifies an accomplishment, since the meaning indicates a telic event:

$$
\begin{aligned}
& \text { pujor-tar-poq } \\
& \text { smoke-REP-IND.3SG } \\
& \text { 'S/he is smoking' }
\end{aligned}
$$

The literal meaning is that the person exhales smoke repeatedly from his mouth. And when it becomes a habit/characteristic, then another -tar has to be added to indicate a generic habit, which is the second meaning of -tar:

$$
\begin{aligned}
& \text { pujor-tar-tar-poq } \\
& \text { smoke-REP-HAB-IND.3SG } \\
& \text { 'S/he smokes' }
\end{aligned}
$$

The generic type of habit also relates to general truths about the habits of animals and the cycles of nature: 


$\begin{array}{lll}\text { avannaani } & \text { ukiu-kkut } & \text { siku-sar-poq } \\ \text { north.LOC } & \text { Winter-VIA } & \text { ice-HAB-IND.3SG }\end{array}$

'In the winter, there is ice (on the water) in the North'

$$
\begin{array}{ll}
\text { qimmi-t } & \text { qilut-tar-put } \\
\text { dog-ABS.pl } & \text { bark-HAB-IND.3SG } \\
\text { 'Dogs bark' } &
\end{array}
$$

The negative habitual has several forms. It is normal to add the negative morpheme - nngit 'negative' after -tar to create -tanngit 'do not V'. But a special form is also used, namely, - neq ajor - 'do not V', which is composed of neq 'abstract participium' and the verb stem ajor- 'does not/bad'.

$$
\begin{aligned}
& \text { pujortar-neq ajor-poq } \\
& \text { smoke-NMLZ do.not-IND.3g } \\
& \text { 'S/he does not smoke' }
\end{aligned}
$$

There is always a choice between using the affix shown in example (15) or using the negative affix - nngit to create pujortatanngilaq 's/he does not smoke'; they both have the same meaning.

To specify that a person never does a specific habitual act, then -nngisaannar 'never' is used.

$$
\begin{aligned}
& \text { qajar-tu-nngisaannar-poq } \\
& \text { kayak-use-never-IND.3SG } \\
& \text { 'S/he has never kayaked' }
\end{aligned}
$$

When using -tar 'iteration, habit', the habit or customary action is general with regard to the time in which the situation occurs, except when an adverb of time is added to indicate that the situation is repeated; for example, every Sunday. When the iterative affix - kula 'often' is used, the meaning is specified to happen 'often' but not 'regularly'. It applies to any kind of verb stem, and it always precedes -tar 'iterative, habitual' if both are used. Here, it is not acceptable to add a punctual adverb of time to indicate that the situation is repeated every Sunday. The meaning of -kula 'often' indicates that the situation is repeated within an interval of time; for example, manna 'now (in this period)', siorna 'last year (during last year)', aasaq 'summer (during summer)' or juullimi 'during Christmas'. This indicates that the situation was repeated often; specifically, 'during last year, summer or Christmas':

$$
\begin{array}{ll}
\text { maanna/siorna/aasaq/juulli-mi } & \text { pulaa }- \text { kula-voq } \\
\text { now/last.year/summer/Christmas-LOC.SG } & \text { visit-often-IND.3SG } \\
\text { 'Now, last year, last summer, during Christmas, s/he visits/visited often' }
\end{array}
$$

The other iterative affix - gajuC, 'often, inclined' is also different from the iterative-habitual -tar, in that it indicates the situation's frequency. Normally, it is used regarding the weather or to refer to something a person does frequently: 
(19)

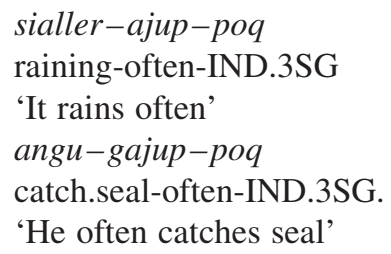

Other, less frequent habitual-iterative affixes are: $-j a$ 'inclined, do easily', which is used mostly with emotional verbs like kamajavoq 's/he becomes angry easily'; - qqatuC - 'rarely', which seems to be added to all kinds of verbs, such as iseqqatuppoq 's/he rarely comes'; -jaallu 'early (habitual)', which is limited to what is done very early, such as 'go to bed early' or 'get up early' in the morning, as in innajaalluvoq 's/he usually goes to bed early', and finally, saannar 'often, frequently', which seems to be used most by the older generation and is added to all kinds of verbs, such as isertaannarpoq 's/he usually comes by'. All of these affixes always precede the general habitual affix -tar, if both are present, as in:

$$
\begin{aligned}
& \text { ukiu-kkut inna-jaallu-sar-poq } \\
& \text { winter-VIA } \quad \text { wake.up-early.habitually-HAB-IND.3SG } \\
& \text { 'In the winter, s/he goes to bed early' }
\end{aligned}
$$

All of these iterative-habitual affixes also precede -tar/-sar 'iterative, habitual', but follow it when the meaning is 'repetition':

$$
\begin{aligned}
& \text { misilit-ta - kula-sar-paat } \\
& \text { test-REP-often-HAB-IND.3.SG.3SG } \\
& \text { 'They usually do the testing often' }
\end{aligned}
$$

To sum up the meanings of -tar:

1. -tar/-sar with the meaning 'repetition' - added to semelfactive verb stems

2. -tar/-sar with the meaning 'repetition' - added to all kinds of verb stems, usually with a quantificational verb (the stem is a verbalized numeral)

3. -tar/-sar with the meaning 'iteration' - denoting a custom that is bound to a specific time, which is added to all kinds of verb stems; obligatory

4. -tar/-sar with the meaning 'general habitual', obligatory

In 1. (repetition), it is only added to the verb's bare (core) verb stem, and it denotes the repetition of a single movement.

In 2. (repetition), it is added to situations in their entirety, often with the repetition affix -qattaar. In this meaning, there is often a quantificational verb to indicate the frequency.

In 3. iteration, it is obligatory when there is a punctual adverb of time; e.g., ataasinngornikkut 'on Mondays', and with the conditional morpheme-gaanga in the causative mood. 
In 4., it has a general habitual meaning and describes a general habit, such as arsartarpoq 's/he plays football'. Here, it does not need to have an adverb of time. The generic habitual meaning seems to belong in this group.

The meanings of -tar 'repetitive, iterative and habitual' seem to have developed in the following way:

Repeated single movement $\rightarrow$ repeated situation/event $\rightarrow$ customary act/iteration $\rightarrow$ habitual

Just as Fortescue (1996) claims, the meanings of -tar have become extended from a concrete meaning to more abstract meanings, and this pattern is parallel to the extension of -sima meanings (Trondhjem 2007). The development also shows that the concrete meaning is close to the verb stem, while the affixes that have developed a more abstract meaning occur further to the right.

The ordering of the other habitual and repetitive affixes seems to be:

Stem + repetition $($ single movement $)+$ repetition of situation + custom/habitual

\section{The ordering of the repetitive, iterative, habitual and inner phasal aspect}

Having seen the order of the repetitive, iterative and habitual aspects, it would be interesting to examine how inner phasal aspectual affixes like -ler 'begin, be about to' or - reer 'conclusive' are placed in relation to the repetitive, iterative and habitual affixes. As already mentioned above, -tar 'habitual' precedes the outer phasal aspect, tense and modality.

In the repetitive meaning of -tar, -ler 'begin' or - reer 'conclusive' would appear to always follow -tar 'repetitive':

$$
\begin{aligned}
& i k u t-\text { ta-ler/-reer-paa } \\
& \text { hack-REP-ING }{ }^{7} / \text {-CONCL-IND.3SG.3SG } \\
& \text { 'S/he has started/finished hacking it' }
\end{aligned}
$$

But it would appear to precede the habitual meaning of -tar:

$$
\begin{aligned}
& \text { ikut-ta-ler /-reer-tar-paa } \\
& \text { hack-REP-ING/-CONCL-HAB-IND.3SG-3SG } \\
& \text { 'S/he usually begins/finishes hacking it' }
\end{aligned}
$$

The other repetitive affixes, such as -qattaar 'repetition' and '-llattaar 'repeated (shortly)', also seem to follow this pattern (appearing after repetitive and before habitual) in some situations:

ikut-ta-qattaa-ler/-reer-tar-paa

hack-REP-REP-ING/-CONCL-HAB-IND.3SG-3SG

'S/he usually begins/has finished hacking it repeatedly'

\footnotetext{
${ }^{7}$ ING - ingressive.
} 
As already mentioned, -taqattaar is a common compound unit that applies to all other kinds of situation types. When the stem is a stative, -taqattaar can follow and/or precede -ler 'begin, be about to', but in this case, the stem would be asanniler - 'fall in love':

asa-nni-ler-taqattaa-ler-tar-poq

love-ANTIP-ING-REP-ING-HAB-IND.3SG

'S/he used to fall in love repeatedly'

In example (24), the first - ler 'begin' has scope over the verb stem asanni- 'love (antipassive)', and the last -ler has scope over the whole situation, asannilertaqattaar - 'fall in love repeatedly'.

In constructions like (24), the compound verbal stem denotes an ingressive situation; e.g. asanniler- 'fall in love', siniler- 'fall asleep', and it seems to behave as a semi-lexicalisation. Using - reer 'conclusive' in the position between the verb stem and an affix of repetition like *asannereeqattaar- 'has fallen out of love repeatedly" would not be acceptable because - reer 'conclusive' always follows the repetition affixes. The ordering of affixes would then be:

Stem $+($ semi- $)$ lexicalized inner phasal aspect + repetition + inner phasal aspect + habitual

\section{Conclusion}

The quantificational affixes of the repetitive, iterative and habitual aspects include about 10 different affixes, of which -tar seems to have developed four distinct meanings: with the meaning 'repetition' only added to semelfactive verb stems; with the meaning 'repetition' added to all kinds of verb stems where a frequentative verb (verbalized numeral) is added; with the meaning 'iterative' bound to regular customs; and with the meaning 'habitual' that is bound to punctual adverbs of time and with the meaning 'general habitual' to denote habits and generic habits. The use of -tar is obligatory in the last two cases. The development of the meanings seems to be:

Repeated single movement $\rightarrow$ repeated situation/event $\rightarrow$ customary act/iteration $\rightarrow$ habitual

The repetitive meaning of -tar is different from other repetitive affixes in that it is only added to semelfactive verb stems, while the others are added to all kinds of verb stems. There are several habitual affixes with more specific meanings, such as -kula 'often' and -gajuC 'often, inclined'. These always precede -tar in the general habitual meaning.

The ordering of the affixes seems to follow the scheme where a concrete meaning is close to the stem and an abstract meaning is close to the inflection, parallel to the pattern of tense affixes that have several meanings, such as -ler with aspectual meanings near the stem and tense meanings near the inflection. It seems that the habitual meaning is within the scope of the outer phasal aspect, but 
the most general meanings are obligatory as tense affixes. The ordering of quantificational affixes and inner phasal aspects shows that repetitive affixes precede the conclusive affix - reer, but the ingressive affix -ler precedes the repetitive affix when used in semi-lexicalized units. The general ordering of productive affixes is then:

Stem + repetitive + inner phasal aspect + habitual + outer phasal aspect + tense + inflection

\section{Notes on contributor}

Naja Blytmann Trondhjem, associate professor in Eskimology and Arctic Studies at the Department of Cross-cultural and Regional Studies, University of Copenhagen has an MA from Ilisimatusarfik, University of Greenland in Nuuk, including a BA in Linguistics at the Department of Linguistics at the University of Copenhagen. Her PhD thesis has the title: Marking of time in West Greenlandic, with a focus on past time, written in Danish. NBT still investigates the marking of time in WG. NBT has taught West Greenlandic at the Eskimology and Arctic Studies since 2000. NBT was born in Upernavik in West Greenland and has West Greenlandic as her first language.

\section{References}

Bergsland, Knut. 1955. A Grammatical Outline of the Eskimo Language of West Greenland. Sug, Switzerland: Interdocumentation Co. Ag.

Berthelsen, Christian, Frederik Nielsen, Birgitte Jacobsen, Robert Pedersen, Inge Kleivan, and Jørgen Rischel. 1990. Oqaatsit Kalaallisuumiit Qallunaatuumut/Grønlandsk Dansk Ordbog. Nuuk: Atuakkiorfik.

Bybee, Joan, Revere Perkins, and William Pagliuga. 1994. The Evolution of Grammar. Chicago: The University of Chicago Press.

Comrie, Bernard. 1976. Aspect. An Introduction to the Study of Verbal Aspect and Related Problems. Cambridge: Cambridge University Press.

Cinque, Guglielmo. 1999. Adverbs and Functional Heads: A Cross-linguistic Perspective. Cary, NC: Oxford University Press.

Egede, Paul. 1760. Grammatica Grönlandica Danico-Latina. Havniæ, Copenhagen: Gottmann. Frid. Kisel.

Fabricius, Otto. 1801. Forsøg til en Forbedret Grønlandsk Grammatica. Kjøbenhavn: Det Kongelige Vaysenhuses Bogtrykkerie.

Fortescue, Michael. 1996. Tense, mood and aspect grammaticalisation in West Greenlandic and Chukchi. In La Dynamique Dans la Langue et la Culture Inuit, ed. N. Teris and M. Therrien, 151-75. Paris: Peeters.

Fortescue, Michael, Steven Jacobson, and Lawrence Kaplan. 1994. Comparative Eskimo Dictionary with Aleut Cognates. Fairbanks, Alaska: Language Center Press.

Hagedorn, Karen. 1987. Aspekt $i$ vestgrønlandsk. København: Institut for Eskimologi, Københavns Universitet.

Kleinschmidt, Samuel. 1871. Den Grønlandske Ordbog. Kjøbenhavn: Louis Kleins Bogtrykkeri, Ministeriet for Kirke- og Undervisningsvæsenet med Det Kongelige Danske Videnskabernes Selskabs Understøttelse.

Kristoffersen, Lars. 1992. Verbal derivation and inflection in a functional grammar of West Greenlandic. In Layered Structure and Reference in a Functional Perspective. Papers from the functional grammar conference in Copenhagen 1990, ed. Michael Fortescue, Peter Harder, and Lars Kristoffersen, 143-71. Amsterdam/Philadelphia: John Benjamins Publishing Company. 
Trondhjem, Naja Blytmann. 2007. Markering af tid i grønlandsk sprog med særlig fokus på fortid., PhD diss., Department of Cross-Cultural and Regional Studies, University of Copenhagen, Copenhagen.

Trondhjem, Naja Blytmann. 2009. The marking of past in Kalaallisut, the Greenlandic language. In Variations on Polysynthesis. The Eskaleut Languages, ed. Marc-Antoine Mahieu and Nicole Tersis. Typological Studies in Language 86. 171-82. Amsterdam/Philadelphia: John Benjamins Publishing Company. 